\title{
A SURVEY OF THERMAL DEGRADATION BEHAVIOR BASED ON CHEMICAL COMPOSITION OF POST-CONSUMED COFFEE
} AND YERBA MATE

\author{
ROBERTA MOTTA NEVES, ${ }^{*}$ LUCAS DALL AGNOL ${ }^{* *}$ and HEITOR LUIZ ORNAGHI JR. ${ }^{* *}$ \\ *Postgraduate Program in Mining, Metallurgical and Materials Engineering, \\ Federal University of Rio Grande do Sul (UFRGS), Av. Bento Gonçalves 9500, \\ 91501-970, Porto Alegre/RS, Brazil \\ ${ }^{* *}$ Federal University for Latin American Integration (UNILA), Foz do Iguaçu, Paraná, Brazil \\ $\square$ Corresponding author: R. Motta Neves, robertamneves@gmail.com
}

Received September 7, 2020

\begin{abstract}
The amount of residues generated from different sources is highly variable as a function of many factors, including the soil, climatic and plant characteristics, as well as the location of the plantation site. In this context, post-consumed yerba mate and coffee are gaining special attention due to their enormous potential to be used for different applications: as reinforcement in polymeric matrices, fertilizers, and in combustion production. Yerba mate is common in the South region of Brazil and it is traditionally consumed by locals. Coffee grounds are also widely available as coffee is consumed around the world. Hence, the present study has as its main objective to study the chemical composition, thermal stability and morphology of post-consumed yerba mate and coffee. Also, the TG curve based on the chemical composition of both residues has been evaluated using a predictive kinetic model. The main results indicate an excellent TG simulated curve based on chemical composition. The results can help to rapidly estimate the thermal degradation behavior of materials for their further applications.
\end{abstract}

Keywords: yerba mate, coffee, post-consumption residues, thermal analysis, thermal degradation prediction

\section{INTRODUCTION}

Brazil is a great country, with a huge consumption of hot non-alcoholic beverages, such as coffee and chimarrão. According to CONAB (Brazilian National Supply Company), in 2019, coffee was cultivated on a total area of 2.16 million hectares. ${ }^{1}$ Besides coffee cultivation, Brazil is the second-largest consumer of coffee beans, behind only the United States of America. These expressive numbers are the result of the reinvention of the coffee industry, launching new trends that offer new experiences for customers. Among these trends, in the coffee market, singledose coffee stands out. According to Associação Brasileira da Indústria de Café (ABIC), more than 1 million tons of coffee were consumed in 2017 , and around 10 tons of this amount was consumed as single-dose coffee. ${ }^{2-4}$

On the other hand, chimarrão is a legacy of the Guarani and Jesuit ethnicities, which inhabited southern Brazil in the past and it is mainly consumed in the Rio Grande do Sul state, Brazil.
Chimarrão is made by the infusion in hot water of Ilex paraguariensis (i.e. yerba mate). The IBGE (Instituto Brasileiro de Geografia e Estatística) estimated that $80 \%$ of yerba mate produced in Brazil in 2018 was destined for the domestic market. ${ }^{5}$ In addition to its social and economic appeal, yerba mate has many beneficial health effects, due to its rich content of compounds such as vitamins $\mathrm{C}, \mathrm{B} 1$, and $\mathrm{B} 2$, phosphorus, iron, calcium, aluminum, which also makes possible its application in alternative medicine, cosmetology and pharmacy. ${ }^{6-8}$

Once both of the aforementioned products have a social and practically ritualistic role in Brazilian society, they generate large amounts of waste. Coffee and yerba mate are both produced from lignocellulosic materials and hence they comprise cellulose, hemicellulose, extractives, and lignin, among other components. Apart from this, understanding their decomposition, with respect to their chemical composition, is 
important, since it determines the physical, mechanical, and chemical properties of such materials. ${ }^{9-15}$

Determining the chemical composition of post-consumed materials is necessary for their possible re-use as reinforcement in polymer composites, ${ }^{16}$ torrefaction for combustion production, ${ }^{17} \quad$ production of nanofibers/nanocomposites, ${ }^{18,19}$ among others. ${ }^{20}$ The further application of such materials has an important environmental role, since it gives the opportunity to avoid disposal in landfills. ${ }^{21}$ Determining the chemical composition provides an insight into the properties of the material to be studied, as aforementioned. To elucidate, a lignocellulosic material that contains a higher amount of hemicelluloses presents greater humidity absorption, while its thermal plateau tends to extend to higher temperatures. ${ }^{22,23}$ The cellulose hinders the heat transfer in the sample (due to the fact that it is a more ordered portion of the biomass), playing a major role in the activation energy of degradation. ${ }^{23,24}$ Lignin has a potential to be used for the production of fuels, chemicals, and various other products. ${ }^{25}$ Hence, these materials are expected to show complex behavior and it is dependent on the proportion among the main components. ${ }^{12,24,26,27}$ In particular, the thermal analysis technique is one of the fundamental ones in biomass science, since it dictates the application of fibers based on their thermal characteristics, such as thermal stability, mass loss as a function of temperature and/or time, and the temperature range in which degradation occurs.

The prediction of properties is of crucial importance because it avoids time-consuming investigations, and allows obtaining results in a cheaper and faster manner. Cabeza et $a l^{28}$ elaborated an autocatalytic kinetic model for TG curves based on the chemical composition of biomasses. From the initial biomass composition, the model is optimized, and the TG curve is estimated. This tool allows a first insight into the thermal degradation characteristics of any lignocellulosic fiber by separating cellulose, hemicelluloses, lignin, oil, and water into different curves. Hence, the effect of any component/proportion, the effect of chemical/physical interactions, and overlap events on degradation can be easily visualized. Another advantage is the possibility of varying the heating rate.
This study has as a major objective to simulate the TG curves based on the chemical composition of post-consumed coffee and yerba mate residues. Other properties were evaluated using the following methods: Fourier-transform infrared spectroscopy (FTIR), and scanning electron microscopy (SEM).

\section{EXPERIMENTAL \\ Materials}

Post-consumed coffee grounds were collected from single-dose coffee capsules, after coffee consumption, and were dried in an oven at $80{ }^{\circ} \mathrm{C}$ for $24 \mathrm{~h}$. The postconsumed yerba mate (Ilex paraguariensis) was collected after consumption and dried in an oven at $110^{\circ} \mathrm{C}$ for $12 \mathrm{~h}$.

\section{Methods}

The chemical components of the post-consumed coffee and yerba mate were determined as follows: lignin (TAPPI T222 om-02), extractives (TAPPI T204 cm-97), cellulose and hemicelluloses, as well as humidity (the Van Soest method). All results were determined in percentage by weight $(\% \mathrm{w} / \mathrm{w})$.

The changes in the chemical composition were analyzed by FTIR (Nicolet device, model IS10 Thermo Scientific), with 32 scans and in the $4000-400 \mathrm{~cm}^{-1}$ wavenumber range by ATR. The deconvolution of the peaks was done using OriginLab 2020b.

The morphology of the post-consumed coffee and yerba mate was analyzed by SEM-FEG (Tescan model FEG Mira 3), the samples were coated with Au, and the acceleration voltage applied was $15 \mathrm{keV}$. The superficial porosity was estimated using the OriginLab $2020 b$.

The non-isothermal degradation of the postconsumed coffee and yerba mate was analyzed by TGA (Shimatzu TGA-50) under $\mathrm{N}_{2}$ atmosphere (50 mL. $\mathrm{min}^{-1}$ rate), with a heating rate of $10^{\circ} \mathrm{C} \cdot \mathrm{min}^{-1}$, from 30 to $600{ }^{\circ} \mathrm{C}$ using a mass of $\sim 10 \mathrm{mg}$. From TG curves, a theoretical study based on Cabeza's free spreadsheet in an Excel file ${ }^{28}$ was performed, and the main chemical components were separated: water, extractives, hemicelluloses, cellulose, lignin, and their respective chars. The program is available at http://hpp.uva.es/software/.

\section{RESULTS AND DISCUSSION}

The results obtained in chemical composition analysis are presented in Figure 1. The results indicate very distinct characteristics for the materials studied. While post-consumed yerba mate has a considerably higher amount of cellulose, hemicelluloses and lignin, as well as higher humidity, in comparison with postconsumed coffee, the latter has a greater amount of ashes and extractives. These differences 
contribute to disparities in physical, chemical, and thermal properties.

The infrared spectroscopy of both residues is presented in Figure 2 (a). Usually, cellulose, hemicelluloses and lignin have a very similar spectroscopy pattern, making it difficult to

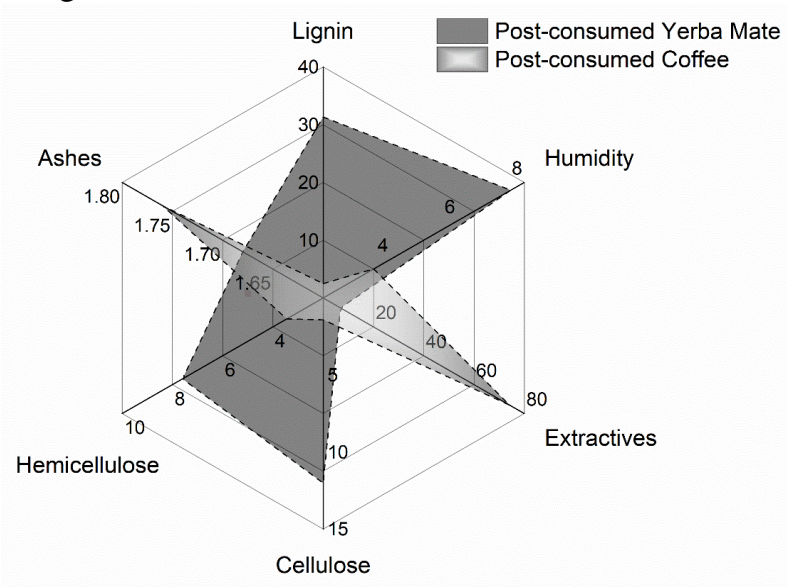

Figure 1: Chemical composition of post-consumed yerba mate and coffee estimated in this study
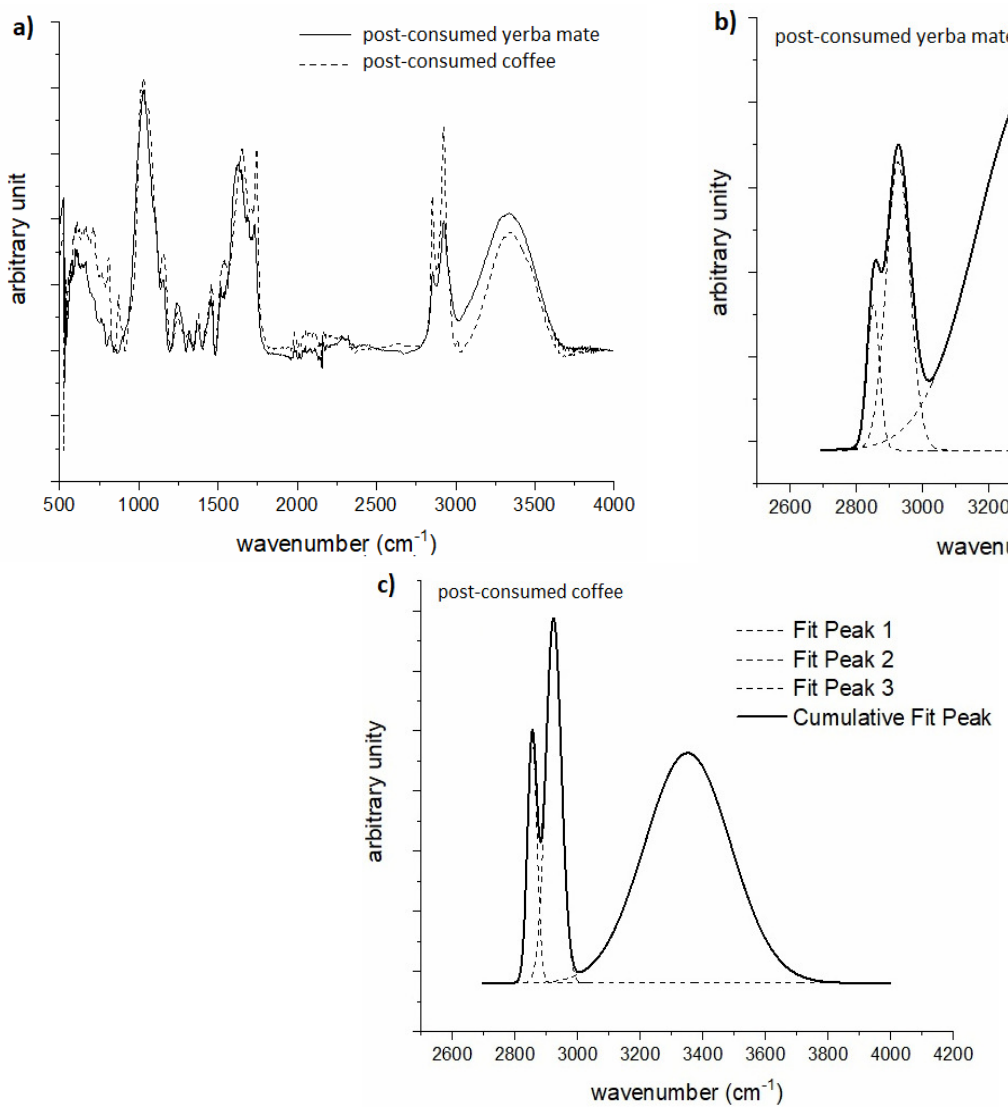

wavenumber $\left(\mathrm{cm}^{-1}\right)$

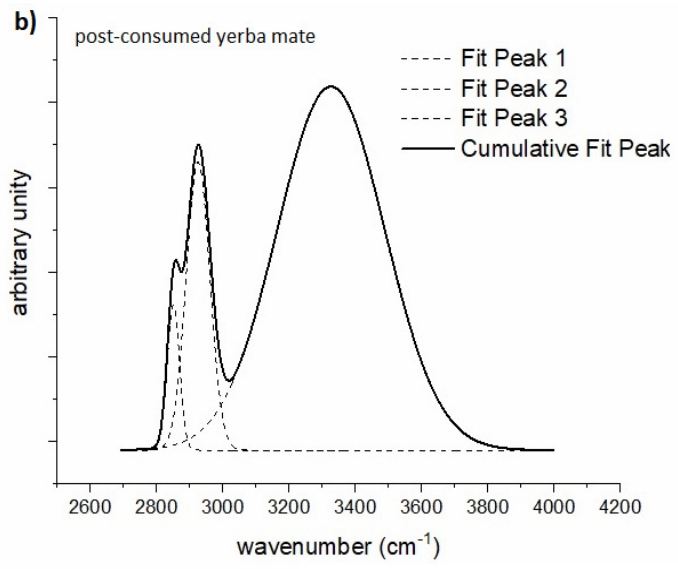

Figure 2: a) Infrared spectra for post-consumed yerba mate and coffee; b) deconvolution of the region $2600-4000 \mathrm{~cm}^{-1}$ for post-consumed yerba mate; c) deconvolution of the region $2600-4000 \mathrm{~cm}^{-1}$ for postconsumed coffee 
It is usual to qualitatively compare the increase/decrease of absorption bands. Based on it, FTIR curves were standardizing in relation to the baseline (for better comparison). Then, only the region in the range of $2600-400 \mathrm{~cm}^{-1}$ was deconvoluted and the characteristic peaks are presented in Figure 2 (b) for post-consumed yerba mate and in Figure 2 (c) for post-consumed coffee. It is noted that the main difference in chemical composition lies in the lower absorption band related to the $\mathrm{OH}$ region (3000-4000 $\mathrm{cm}^{-1}$ ) and higher absorption of the peaks located around $2700 \mathrm{~cm}^{-1}$.The decrease in the absorption band ratio for $\mathrm{OH}$ groups can be attributed to a small content of cellulose, hemicelluloses, and lignin, which have a greater contribution to this band. The higher amount of extractives seems to have a greater contribution to the bands at $2900 \mathrm{~cm}^{-1}$ due to $\mathrm{CH}_{3}$ stretching vibration of alkyl groups in the aliphatic bonds of cellulose, hemicelluloses, and lignin. ${ }^{16,30}$ Hence, even when comparing samples with very different amounts of components, it becomes very difficult to distinguish between the spectra.

The spectra for both materials will be discussed separately for a better understanding. Regarding post-consumed yerba mate (Fig. 2a), some important characteristic bands, such as that at $3300 \mathrm{~cm}^{-1}(\mathrm{OH}$ vibration of the hydroxyl groups of cellulose, hemicelluloses and lignin), $2900 \mathrm{~cm}^{-1}$ (CH stretching vibration), 1635-1580 $\mathrm{cm}^{-1}$ (OH bending of absorbed water), and 1035 $\mathrm{cm}^{-1}$ (CO deformation at carbon six in cellulose) are reported by some authors. ${ }^{31-34}$ For postconsumed coffee, some authors related the band at $3300 \mathrm{~cm}^{-1}$ with different vibration modes of $\mathrm{OH}$, including intra- and inter-molecular $\mathrm{OH}$ bonds and free $\mathrm{OH}$. Around $2900 \mathrm{~cm}^{-1}$, the two bands refer to both asymmetric and symmetric stretching of $\mathrm{CH}$ bonds in aliphatic chains of caffeine. Around $1740 \mathrm{~cm}^{-1}, 1635 \mathrm{~cm}^{-1}, 1452 \mathrm{~cm}^{-1}$ and $1000 \mathrm{~cm}^{-1}$, there is the vibration of $\mathrm{C}=\mathrm{O}$ (in aliphatic esters), $\mathrm{C}=\mathrm{C}$ stretching of lignin moieties, $\mathrm{CH}$ bending from $\mathrm{CH}_{3}$ groups, and the axial deformation of the $\mathrm{CO}$ groups from chlorogenic acids. Other bands, such as those from $1375 \mathrm{~cm}^{-1}$ to $1159 \mathrm{~cm}^{-1}$, can be also related to chlorogenic acids. ${ }^{35-39}$

For both spectra, the region at $2600-4000 \mathrm{~cm}^{-1}$ was deconvoluted, aiming to better understand the difference between them. The center maximum of the two peaks before $3000 \mathrm{~cm}^{-1}$ was practically the same (2850/2854 and 2924/2923, respectively for post-consumed yerba mate/coffee), but the full width at half height maximum (FWHM) reached higher wavenumbers for yerba mate (44/36 and $84 / 58$ for post-consumed yerba mate/coffee). The maximum height for both peaks was 20 and 30 for post-consumed coffee, and 9 and 17 for postconsumed yerba mate. On the other hand, the deconvoluted curve attributed to the $\mathrm{OH}$ vibration modes presented a center maximum of 3326 for post-consumed yerba mate and 3351 for postconsumed coffee. The maximum height was 21 for post-consumed yerba mate and 19 for postconsumed coffee, while the FWHM was 382 for post-consumed yerba mate and 322 for postconsumed coffee. The correlation coefficient of both curves was $r^{2}=0.99$. Hence, the qualitative analysis gives an insight into the influence of chemical composition on the FTIR pattern.

Figure 3 presents the surface characteristics of the samples studied. According to the reference scale presented in each SEM image, it is possible to estimate that the diameter measured for the post-consumed coffee is around $288.29 \pm 118.89$ $\mu \mathrm{m}$, while for post-consumed yerba mate an average rod-shape form of $1.96 \pm 0.33 \mathrm{~mm}$ is observed. Other important superficial characteristics noted for post-consumed coffee were surface irregularity and porosity, while for post-consumed yerba mate, the particles are predominantly rod-shaped. ${ }^{40}$ The yerba mate was sieved (<35 mesh) aiming to homogenize the average particle size.

Figures 4 and 5 present the porosity estimates based on the SEM samples, following Abdullah's study, ${ }^{41}$ using the free Excel sheet available to the authors. The results showed a porosity value of $49.12 \%$ for post-consumed yerba mate and of $69.70 \%$ for post-consumed coffee. This result is important because higher superficial roughness allows higher mechanical resistance due to better interaction with the matrix. On the other hand, higher porosity allows easier heat transfer through the sample.

The TG curves of both residues are presented in Figure 6. It is noted that, in spite of the higher humidity content present in post-consumed yerba mate (Fig. 6 a), it shows lower mass loss at 100 ${ }^{\circ} \mathrm{C}$, suggesting that other components are also important for thermal stability. The higher mass remaining for post-consumed yerba mate can be attributed to its higher lignin content. Also, it is noteworthy that, in spite of the higher cellulose, hemicelluloses and lignin contents present in 

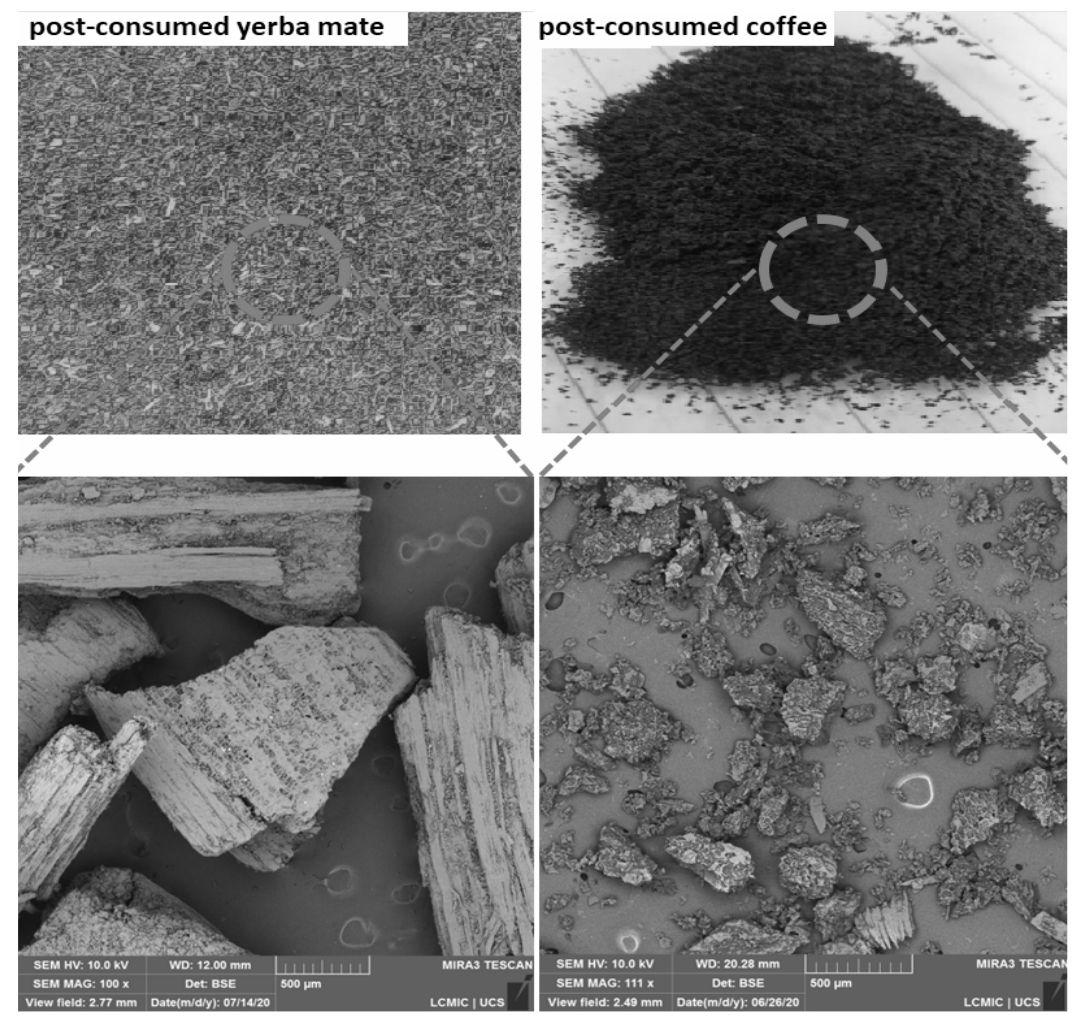

Figure 3: SEM micrographs for yerba mate and coffee grounds

\section{post-consumed yerba mate}
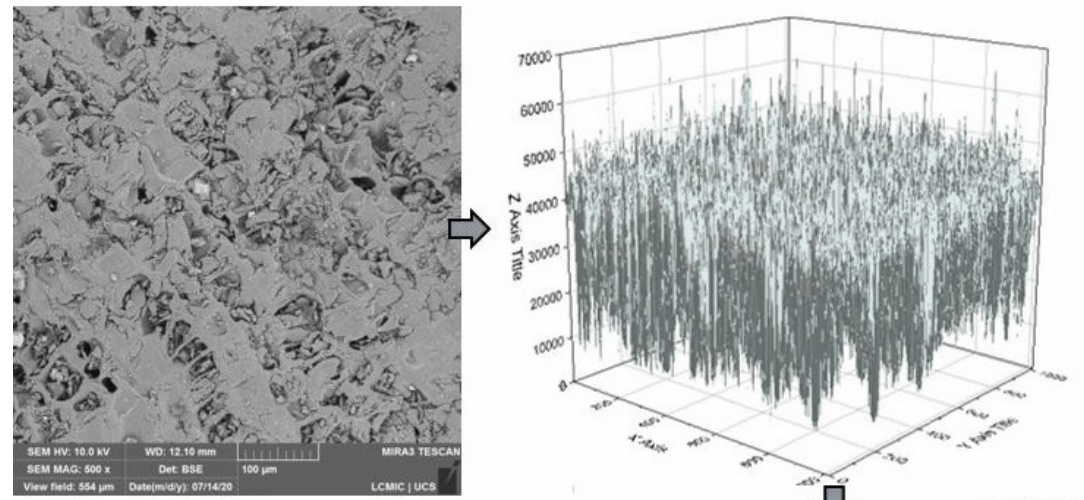

\begin{tabular}{c|c|c} 
& Parameter & Yerba mate \\
\hline Origin & $H \max$ (grayscale bar) & $6,56 \mathrm{E}+04$ \\
\hline Origin & Hmin (grayscale bar) & 3800 \\
\hline Origin & $\mathrm{x}$ (dimensions) & 1017 \\
\hline Origin & $\mathrm{y}$ (dimensions) & 1016 \\
\hline & V solid & $6,3856 \mathrm{E}+10$ \\
\hline & V under hmin & 3926433600 \\
\hline Origin & V integrate & $3,6412 \mathrm{E}+10$ \\
\hline & V pori & $3,137 \mathrm{E}+10$ \\
\hline & porosity & 0,49126343 \\
\hline & porosity (\%) & 49,1263431 \\
\hline
\end{tabular}

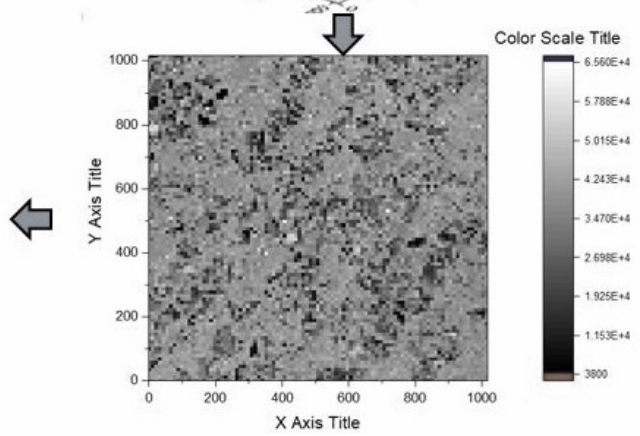

Figure 4: Estimation of superficial porosity for post-consumed yerba mate 


\section{post-consumed coffee}
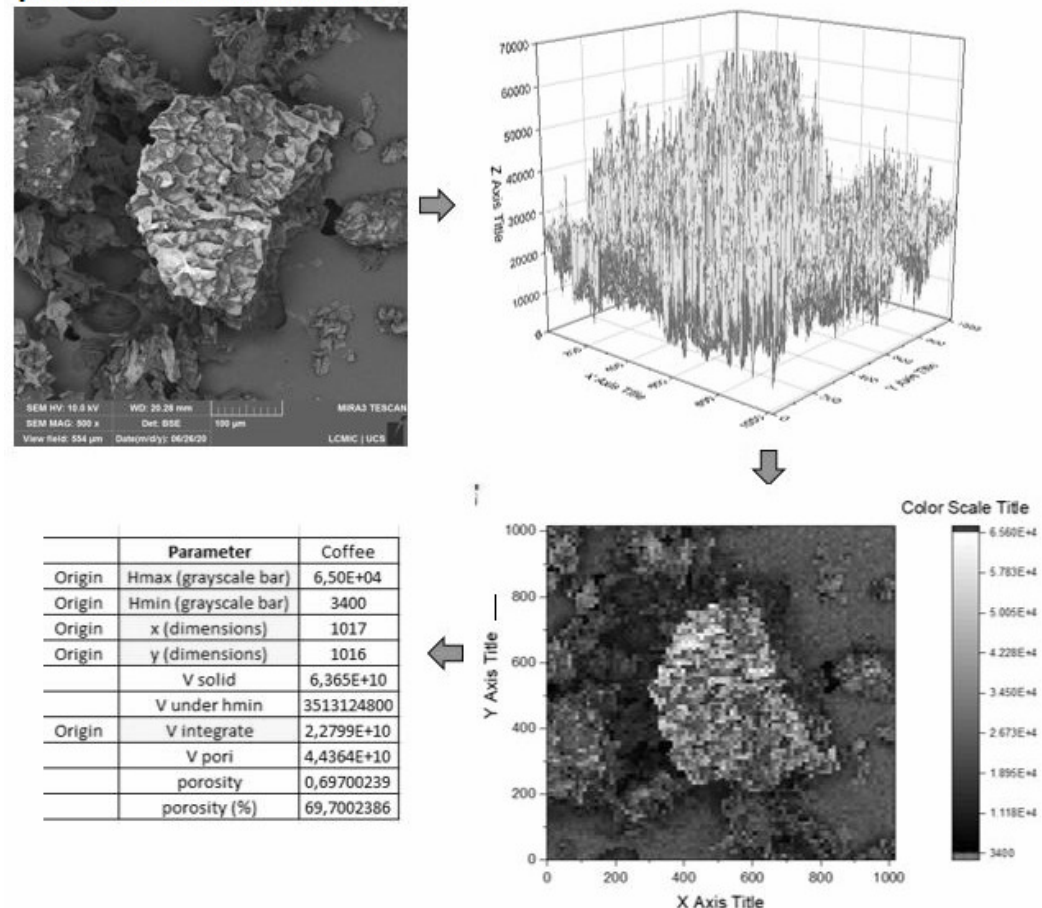

Figure 5: Estimation of superficial porosity for post-consumed coffee
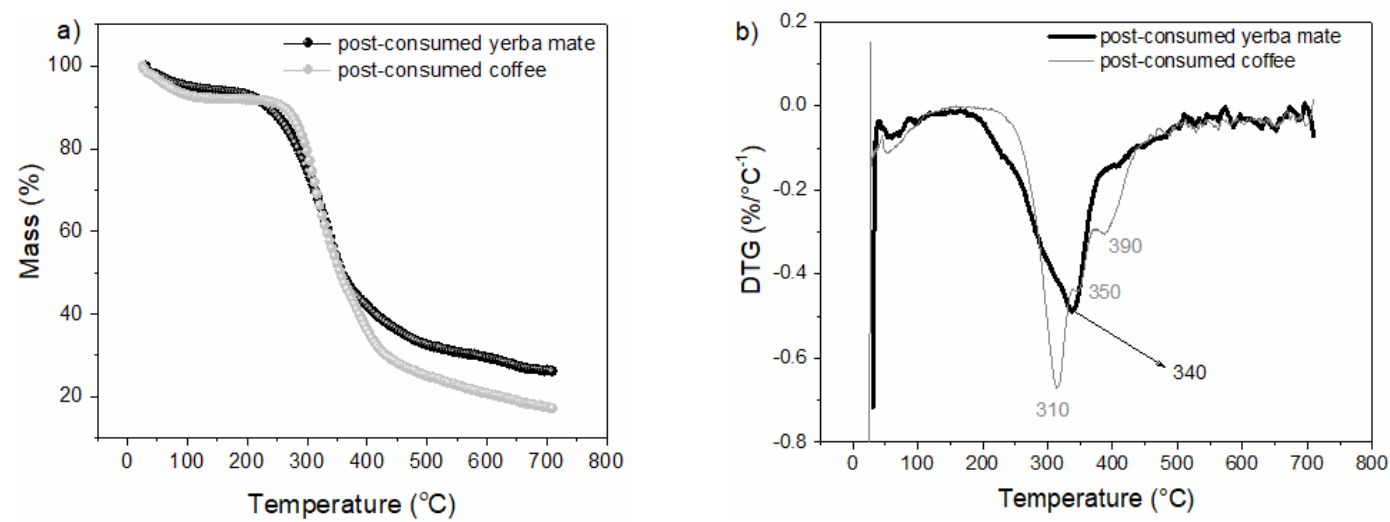

Figure 6: a) TG and b) DTG curves for post-consumed yerba mate and coffee grounds

According to the DTG analysis, the main peak at $340{ }^{\circ} \mathrm{C}$ is observed for post-consumed yerba mate, while tree different peaks in the same region are observed for post-consumed coffee ${ }^{42}$ $\left(310^{\circ} \mathrm{C}, 350{ }^{\circ} \mathrm{C}\right.$ and $\left.390{ }^{\circ} \mathrm{C}\right)$. This difference can be attributed to a more heterogeneous degradation process occurring in a narrower degradation temperature range. In spite of the lower amount of cellulose, hemicelluloses and lignin in postconsumed coffee, when compared to postconsumed yerba mate (Fig. 1), the higher amount of extractives seems to determine this heterogeneity. It is noteworthy that the characteristic pattern of DTG and TG curves is maintained in spite of the huge differences in the chemical composition of the analyzed materials. ${ }^{42-}$ 45

Figure 7 (a-b) shows the TG curves simulated using the chemical composition obtained according to Figure 1. The experimental TG curve was also plotted within for comparison. The simulated composition obtained for postconsumed yerba mate was as follows: moisture: $8.0 \%$, extractives: $20.0 \%$, hemicelluloses: $25.0 \%$, 
cellulose: 15.0\%, and lignin: $31.4 \%$. The simulated composition for post-consumed coffee was: moisture: $8.0 \%$, extractives: $20.0 \%$, hemicelluloses: $15.9 \%$, cellulose: $27.1 \%$, and lignin: $17.6 \%$. The higher difference between the experimental and simulated TG curves for postconsumed coffee is responsible for the higher difference among the new components obtained in comparison with the predicted values.

Figures 7 (c-d) illustrates each chemical component from the simulated TG curve. This is particularly interesting because it gives an insight into the role of each component and the respective degradation temperature range. The influence of lignin on the final tail of the TG curves can be clearly seen. For the post-consumed yerba mate,
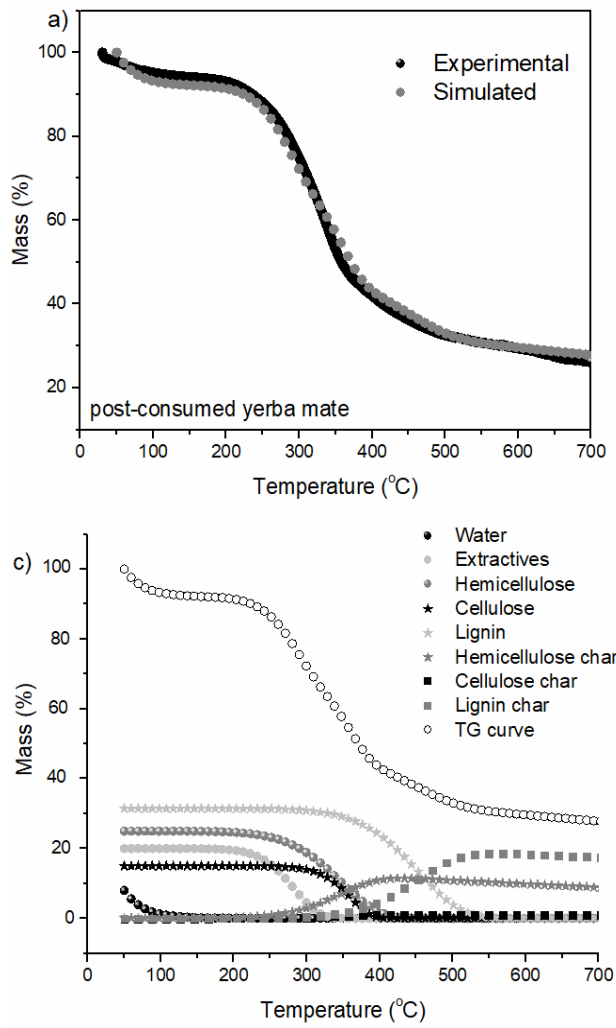

Figure 7: Experimental and simulated curves for (a) yerba mate and (b) coffee grounds; separated components

of (c) yerba mate and (d) coffee grounds

The differences between the experimental and simulated curves for post-consumed coffee grounds, while the curves were very similar for post-consumed yerba mate, clarify that the decomposition profile and the components that contribute to it change drastically with the type of biomass. However, the presence of similar amounts of the components in the biomass composition must lead to following the same
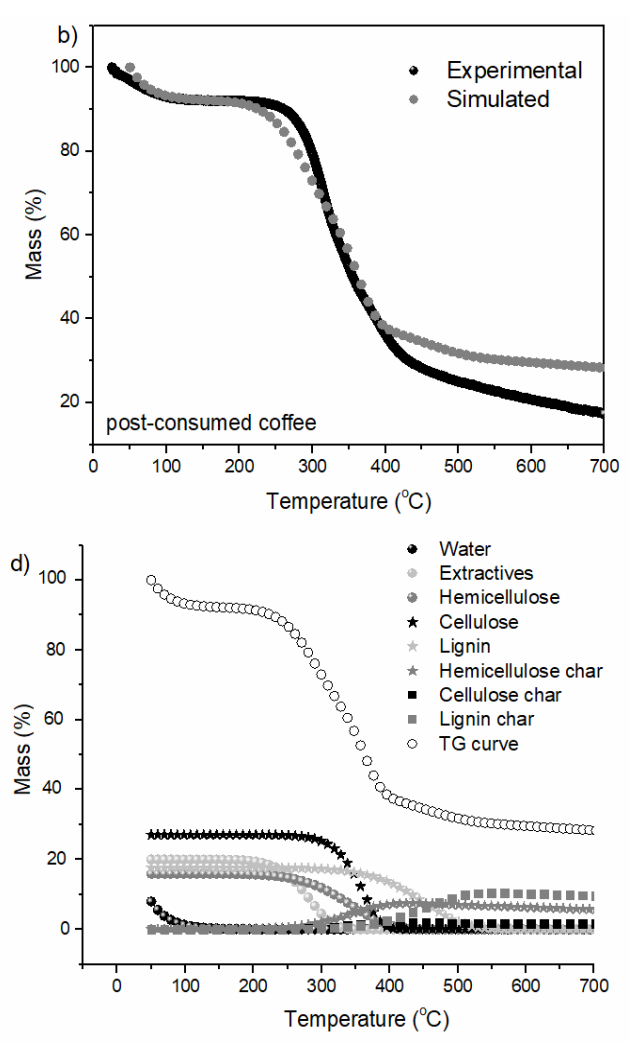

the higher amount of lignin present in the biomass is responsible for a more smooth mass loss after the degradation of cellulose. It is also easy to note that the hemicelluloses and cellulose degrade basically in the same temperature range, while lignin degrades more significantly in the final stage of the previous components. If a significant amount of hemicelluloses is present in the biomass, a shoulder in the DTG curve is easily observed. Also, the evolution of the char formation of hemicelluloses, cellulose, and lignin can be noted. All the observations are very important in the pyrolysis research area, mainly in the development of new degradation models based on a more realistic approach. ${ }^{43-45}$

trend. Since most biomasses have a more similar composition to that of post-consumed yerba mate than to that of coffee grounds, the determination of TG curves using the chemical composition and vice versa is highly viable, since the shape of simulated curve was similar to that of the experimental curve. It is possible that the discrepancies between the curves of coffee grounds are caused by the very low amounts of 
lignin, hemicelluloses and cellulose found in the chemical composition analysis. The amounts determined are very different from the ones usually found in lignocellulosic fibers.

\section{CONCLUSION}

Post-consumed coffee and yerba mate residues have been gaining increasing research attention due to their enormous potential to be used in applications such as reinforcement in polymer matrices, fertilizers, combustion production, among others. Knowing the chemical composition of these materials is the first step towards their conscious reuse. In addition, understanding the thermal stability of such materials is essential for more noble applications, for example, as reinforcement fibers. In this context, the present study evaluated the chemical composition and morphology of these residues and the applicability of Cabeza's model to determining the TG curves using the chemical composition. Regarding the biomass morphology, greater irregularity and superficial porosity was found for ground coffee, compared to yerba mate. From the chemical composition, using a kinetic model, it was possible to predict the thermal degradation curves of these materials with an excellent overlap between the simulated curve and that obtained experimentally, mainly for postconsumed yerba mate. For the coffee grounds, the experimental TG curve did not fit well with the simulated one. The main reason can be attributed to its very low cellulose, hemicelluloses and lignin content, which made difficult the calculation. Since most biomasses have similar chemical composition to that of post-consumed yerba mate, it is plausible to use this model as a first approach to rapidly determine the TG curve shape for all biomasses with similar chemical composition. These results present interest in the pyrolysis research area, mainly for the development of new degradation models based on a realistic approach.

ACKNOWLEDGMENTS: The authors would like to thank $\mathrm{CNPq}$ (Process number: 151438/2020-0) and CAPES for financial support.

\section{REFERENCES}

1 Conab, Companhia Nacional de Abastecimento, $2^{\mathrm{o}}$ Levantamento de café - Safra 2019 (2019), https://www.conab.gov.br/info-

agro/safras/cafe/boletim-da-safra-de-cafe/item/113682-levantamento-de-cafe-safra-2019
2 Euromonitor Consulting, Tendências do mercado de cafés em 2017 (2017), http://consorciopesquisacafe.com.br/arquivos/consorci o/consumo/tendencias_do_mercado_cafe_2017.pdf 3 A. S. C. de Bomfim, M. Maciel, H. J. C. Voorwald, K. Benini, D. M. de Oliveira et al., Waste Manag., 83, 123

(2019),

https://doi.org/10.1016/j.wasman.2018.11.006

4 L. Abuabara, A. Paucar-Caceres and T. BurrowesCromwell, Int. J. Prod. Res., 57, 7269 (2019), https://doi.org/10.1080/00207543.2019.1629664

5 IBGE, Brazilian Institute of Geography and Statistics, Production of Vegetable Extraction and Silviculture, 2014, https://sidra.ibge.gov.br/tabela/289

6 B. Gullón, G. Eibes, M. T. Moreira, R. Herrera, J. Labidi et al., Ind. Crop. Prod., 113, 398 (2018), https://doi.org/10.1016/j.indcrop.2018.01.064

A. C. W. Heemann, R. Heemann, P. Kalegari, M. R. Spier and E. Santin, Braz. J. Food. Technol., 22 (2019), https://doi.org/10.1590/1981-6723.22217

P. Kungel, V. G. Correa, R. C. G. Correa, R. A. Peralta, M. Sokovic et al., Int. J. Biol. Macromol., 114, 1161 https://doi.org/10.1016/j.ijbiomac.2018.04.020

9 M. Poletto, H. L. Ornaghi Jr. and A. J. Zattera, $\begin{array}{lllll}\text { Materials } & \text { (Basel), } & \text { 7, } & 6105 & \text { (2014), }\end{array}$ https://doi.org/10.3390/ma7096105

10 C. R. Correa, T. Hehr, A. Voglhuber-Slavinsky, Y. Rauscher and A. Kruse, J. Anal. Appl. Pyrol., 140, 137 (2019), https://doi.org/10.1016/j.jaap.2019.03.007

11 A. O. Avcioğlu, M. A. Dayığglu and U. Türker, Renew. Energ., 138, $610 \quad$ (2019), https://doi.org/10.1016/j.renene.2019.01.053

12 P. H. F. Pereira, N. F. Souza, H. L. Ornaghi Jr. and M. R. de Freitas, Ind. Crop. Prod., 150, 112305 (2020), https://doi.org/10.1016/j.indcrop.2020.112305

13 C. Hernández, C. Escamilla-Alvarado, A. Sánchez, E. Alarcón, F. Ziarelli et al., Biofuel Bioprod. Biorefin., 13, 1143 (2019), https://doi.org/10.1002/bbb.2017

14 H. L. Ornaghi Jr., A. G. d. O. Moraes, M. Poletto, A. J. Zattera and S. C. Amico, Cellulose Chem. Technol., $\quad 50, \quad 15 \quad$ (2016), https://www.cellulosechemtechnol.ro/pdf/CCT1(2016) /p.15-22.pdf

15 M. Poletto and H. L. Ornaghi Jr. (Eds.), "Cellulose: Fundamental Aspects and Current Trends". BoDBooks on Demand, IntechOpen, 2015, https://doi.org/10.5772/59889

16 A. L. Catto, M. A. Dahlem Jr., B. Hansen, E. L. Francisquetti and C. Borsoi, Compos. B Eng., 174, 106935 (2019), https://doi.org/10.1016/j.compositesb.2019.106935

17 Y. Niu, Y. Lv, Y. Lei, S. Liu, Y. Liang et al., Renew. Sust. Energ. Rev., 115, 109395 (2019), https://doi.org/10.1016/j.rser.2019.109395

18 C.-W. Yang and H.-M. Choi, Cellulose Chem. Technol., $\quad 54, \quad 247 \quad$ (2020), 
https://doi.org/10.35812/CelluloseChemTechnol.2020. 54.26

19 R. M. Neves, K. S. Lopes, M. V. G. Zimmermann, M. Poletto and A. J. Zattera, Cellulose, 26, 4417 (2019), https://doi.org/10.1007/s10570-019-02392-2

20 M. A. Solle, J. Arroyo, M. H. Burgess, S. Warnat and C. A. Ryan, Compos. Part A Appl. Sci. Manuf., 124, 105441 (2019),

https://doi.org/10.1016/j.compositesa.2019.05.009

21 N. Hamzah, K. Tokimatsu and K. Yoshikawa, Sustainability, 11, 1060 (2019), https://doi.org/10.3390/su11041060

22 H. Yang, R. Yan, H. Chen, D. H. Lee and C. Zheng, Fuel, 86, 1781 (2007), https://doi.org/10.1016/j.fuel.2006.12.013

23 H. L. Ornaghi, Jr., F. G. Ornaghi, K. C. C. de Carvalho Benini and O. Bianchi, Cellulose, 26, 7145 (2019), https://doi.org/10.1007/s10570-019-02610-x

24 H. L. Ornaghi, Jr., F. G. Ornaghi, R. M. Neves, F. Monticeli and O. Bianchi, Cellulose, 27, 4949 (2020), https://doi.org/10.1007/s10570-020-03132-7

25 X. Chen, H. Li, S. Sun, X. Cao and R. Sun, Sci. Rep., 6, 39354 (2016), https://doi.org/10.1038/srep39354

${ }^{26}$ K. C. C. de Carvalho Benini, H. L. Ornaghi, Jr., P. H. F. Pereira, L. J. Maschio, H. J. C. Voorwald et al., J. Therm. Anal. Calorim., 143, 73 (2020), https://doi.org/10.1007/s10973-019-09221-5

27 T. Hosoya, H. Kawamoto and S. Saka, J. Anal. Appl. $\quad$ Pyrol., $\quad$ 80, $118 \quad$ (2007), https://doi.org/10.1016/j.jaap.2007.01.006

28 A. Cabeza, F. Sobrón, F. M. Yedro and J. GarcíaSerna, Fuel, 148, $212 \quad$ (2015), https://doi.org/10.1016/j.fuel.2015.01.048

${ }^{29}$ R. Kempaiah, G. Gurappa, R. Tomar, M. Poletto, H. L. Ornaghi Jr. et al., Cellulose Chem. Technol., 54, 187 (2020), https://doi.org/10.35812/CelluloseChemTechnol.2020. 54.21

30 X. Zhu, Y. Dong, X. Lu, H. A. N. Que, Y. Zhang et al., Cellulose Chem. Technol., 53, 53 (2019), https://doi.org/10.35812/CelluloseChemTechnol.2019. 53.06

31 S. Xiao, R. Gao, Y. Lu, J. Li and Q. Sun, Carbohyd. Polym., 119, $202 \quad$ (2015), https://doi.org/10.1016/j.carbpol.2014.11.041
32 K.-Y. Lee, Y. Aitomäki, L. A. Berglund, K. Oksman and A. Bismarck, Compos. Sci. Technol., 105, 15

(2014),

https://doi.org/10.1016/j.compscitech.2014.08.032

33 R. M. Neves, H. L. Ornaghi Jr., A. J. Zattera and S. C. Amico, Carbohyd. Polym., 230, 115595 (2020), https://doi.org/10.1016/j.carbpol.2019.115595

34 J. J. Poon, M. C. Tan and P. L. Kiew, Cellulose Chem. Technol., 54, $725 \quad$ (2020), https://doi.org/10.35812/CelluloseChemTechnol.2020. 54.72

35 R. M. Neves, K. Silveira Lopes, M. G. V. Zimmermann, M. Poletto and A. J. Zattera, J. Nat. Fibers, $17, \quad 1355 \quad$ (2019), https://doi.org/10.1080/15440478.2019.1568346

36 M. N. Clifford, J. Kirkpatrick, N. Kuhnert, H. Roozendaal and P. R. Salgado, Food Chem., 106, 379 (2008),

https://doi.org/10.1016/j.foodchem.2007.05.081

37 D. Pujol, C. Liu, J. Gominho, M. À. Olivella, N. Fiol et al., Ind. Crop. Prod., 50, 423 (2013), https://doi.org/10.1016/j.indcrop.2013.07.056

38 A. P. Craig, A. S. Franca and L. S. Oliveira, $L W T$, 47, 505

(2012), https://doi.org/10.1016/j.lwt.2012.02.016

39 L. K. Lazzari, V. B. Zampieri, R. M. Neves, M. Zanini, A. J. Zattera et al., Cellulose, 26, 1231 (2018), https://doi.org/10.1007/s10570-018-2111-x

${ }^{40}$ L. F. Ballesteros, J. A. Teixeira and S. I. Mussatto, Food Bioproc. Tech., 7, $3493 \quad$ (2014), https://doi.org/10.1007/s11947-014-1349-z

${ }^{41}$ M. Abdullah and K. Khairurrijal, Indones. J. Phys., 20, 37

(2009), http://ijphysics.com/index.php/ijp/article/view/194 ${ }^{4}$ V. Bejenari and G. Lisa, Cellulose Chem. Technol., 53 , 861

(2019), 10.35812/CelluloseChemTechnol.2019.53.83

43 A. Murty Kanury, Combust. Flame, 18, 75 (1972), https://doi.org/10.1016/s0010-2180(72)80228-1 ${ }_{44}$ X. Gao, Y. Zhang, B. Li and X. Yu, Energ. Convers. Manag., $108,120 \quad$ (2016), https://doi.org/10.1016/j.enconman.2015.10.070

${ }^{45}$ G. Dorez, L. Ferry, R. Sonnier, A. Taguet and J. M. Lopez-Cuesta, J. Anal. Appl. Pyrol., 107, 323 (2014), https://doi.org/10.1016/j.jaap.2014.03.017 